M. A. J. Rosenberg

J. Ross

A. M. Rouncefield

A. Rourke

A. Roy

D. H. Roy

M. Roy

E. R. Rue

A. J. Rugg

D. Rumball

M. A. H. Russell

J. Rutter

M. L. Rutter

K. Saedi

M. V. Sahami

I. Sakinofsky

M. M. Salzmann

A. Samad

Y. Sann Sann

W. Sarhan

P. N. Sarkar

G. Sarwer-Foner

L. G. Scarth

K. Schapira

K. E. Schmidt

B. C. Scully

C. P. Seager

J. M. Seargeant

M. Segal

U. P. Seidel

R. Seifert

M. A. Sevitt

M. E. Shariatmadari

V. K. Sharma
G. K. M. Shaw

L. Sheldon

T. E. Sicks

G. S. Sidhu

M. M.Simpson

A. C. P. Sims

H. M. Singh

A. Sittampalam

Z. T. Slattery

N. R. Smeyatsky

I. D. Smith

J. E. Smith

R. P. Snaith

B. A. Snowdon

R. A. Solomon

J. M. Speirs

V. Spotswood

W. B. Spry

H. Stalker

H. Standish-Barry

M. T. Stather-Dunn

A. Stedford

R. Steel

B. Steinberg

D. A. Stephens

G. Stern

K. M. Stevenson

G. S. Stirling

R. F. Stirton

D. Storer

P. B. Storey

J. S. Strang

D. Surridge

H. S. Swad
J. L. Swift

P. E. Sylvester

W. R. Taff

A.C. Tait

D. H. H. Tait

W. A. Tait

A. Takriti

J. S. Talbot

W. Tang

M. M. Tannahill

J. I. Taylor

D. D. Thompson

M. E. Thomson

I. G. Thomson

A.S. Thorley

D. R. Thornber

A. R. Tomison

R. M. Toms

C. M. Tonks

B. Toone

L. Treliving

W. H. Trethowan

G. Tufnell

P. J. Tyrer

M. Van Beinum

C. Y. Van Duuren

D. Veltman

V. V. Venugopalan

G. E. Vincenti

J. E. G. Vincenzi

E. J. A. Vogler

G. G. Wallis

C. J. Wardle
W. D. Walker

K. M. Wartnaby

M. A. T. Waters

T. C. Waters

J. P. Wattis

M. A. Watts-Tobin

A. E. Weatherhead

M. G. T. Webb

W. A. Weston

D. P. Wheatley

A. White

H. V. White

J. McN. White

J. S. Whiteley

A. Wieck

S. D. Wignarajah

D. G. Wilkinson

J. Wilkinson

A. C. Williams

D. D. R. Williams

J. A. Williams

P. Williams

V. A. Wills

T. Win

J. K. Wing

P. I. M. Winn

P. J. W. Wood

The Baroness Wootton

B. F. Wright

N. M. Yousufzai

F. Yu Chi Shing

B. C. Yule

M. A. Zaman

If your name has been omitted from this list could you please contact the Secretary to ensure that it is included on any future list.

\title{
Council Resolution on Apartheid
}

At the Council meeting held on 18 March 1987 Council accepted the Resolution passed at the Quarterly meeting on 28 January 1987 and endorsed this as College policy. (The Resolution was published in the Bulletin (March 1987, 11, 105).

Any member considering a visit to South Africa should therefore carefully consider the wording of the Nassau Accord and the Resolution expressing the College views. It should be noted that this Resolution does not preclude United Kingdom members of the College from visiting
South Africa (though attending official functions might be interpreted as condoning apartheid). It should also be noted that the Resolution does not preclude South African members of the College from attending College meetings in the United Kingdom nor from receiving the Journal. The Accord recommended "discouragement of all cultural and scientific events, except where these contribute towards the ending of apartheid or have no possible role in promoting it." 